\title{
Coexistence of resistance to thyroid hormone and ectopic thyroid: ten-year follow-up
}

Man-Li Guo', Xiao Zheng', Liu-Xue Yang²,

Ya-Li Qiu', Liang Cheng', Shao-Gang Ma'

\section{SUMMARY}

Resistance to thyroid hormone (RTH) coexisting with ectopic thyroid is rare. Here we report a case of RTH with ectopic thyroid. A ten-year-old girl had been misdiagnosed as congenital hypothyroidism and treated with levothyroxine since she was born. Ten-year follow-up showed that the elevated thyrotropin was never suppressed by levothyroxine and no signs indicating hyperthyroidism or hypothyroidism despite elevated FT3 and FT4 levels. Therefore the girl developed no defects in physical and cognitive development. Pituitary adenoma was excluded by magnetic resonance imaging. Ultrasonography did not find the thyroid gland in the normal place, while the thyroid scan found a large lingual thyroid gland. The octreotide inhibition test showed a reduction in thyrotropin by $41.98 \%$. No mutation was detected in the thyroid hormone receptor (THR) $\beta, T H R \alpha$, thyrotropin receptor (TSHR), and GNAS1 genes. To our knowledge, it is an interesting RTH case coexisting with lingual thyroid. Arch Endocrinol Metab. 2016;60(6):601-4

\author{
1 Department of Endocrinology \\ and Metabolism, Huai'an Hospital \\ Affiliated to Xuzhou Medical \\ College and Huai'an Second \\ People's Hospital, Huai'an, China \\ ${ }^{2}$ Department of Endocrinology \\ and Metabolism, the Second \\ Hospital Affiliated to Guilin \\ Medical College, Guilin, China \\ ${ }^{3}$ Department of Neonatal Screening \\ and Care, Women and Children's \\ Hospital of Suqian, Suqian, China \\ Correspondence to: \\ Shao-Gang Ma \\ mashaogang@163.com \\ Received on Oct/27/2015 \\ Accepted on Jul/4/2016 \\ DOI: 10.1590/2359-3997000000214
}

\section{INTRODUCTION}

$\mathrm{R}$ esistance of thyroid hormone $(\mathrm{RTH})$ is a rare genetic disease characterized by reduced tissue sensitivity to thyroid hormone. The hallmark of RTH is elevated circulating thyroid hormones with unsuppressed thyrotropin (TSH) (1). Most of RTH cases are caused by a mutation in the thyroid hormone receptor (THR) $\beta$ gene (2). Recently, several reports described the RTH patients due to heterozygous truncating mutations in THR $\alpha$ (3). The clinical presentation of RTH is highly variable including hyperthyroidism, hypothyroidism and asymptomatic. Detection of RTH by a positive neonatal TSH screening test has been described in rare cases (4).

Ectopic thyroid is a rare embryological aberration. Together with thyroid agenesis and hypoplasia, thyroid ectopy is classified as thyroid dysgenesis. Whereas the mutations in the NKX2-1, PAX8, FOXE1, NKX25 , TSHR genes have been reported in a minority of patients with thyroid dysgenesis (5). Lingual thyroid accounts for approximately $90 \%$ of ectopic thyroid tissue. However, the incidence is close to approximately
$1: 100,000$. The majority of patients with lingual thyroid are asymptomatic $(6,7)$. Subclinical and overt hypothyroidism can be observed in some patients, while hyperthyroidism is uncommon (8-10). The inactivating mutations in the guanine nucleotide binding subunit l gene (GNASI) that encodes G protein $\alpha$-subunit and causes mild TSH resistance in pseudohypoparathyroidism (PHP) type Ia is significantly rare (11).

The coexistence of RTH and ectopic thyroid is extremely rare and is difficult to distinguish, three cases have been reported (12-14). Here we describe an unusual patient with RTH and ectopic thyroid. We decided to screen the mutations in the THR $\alpha, T H R \beta$, TSHR, and GNASI genes in the study. The patient in the present study was followed up for ten years.

\section{CASE REPORT}

The girl was born at 39 weeks in June, 2005. Newborn screening after birth revealed that the serum TSH level was $36.9 \mu \mathrm{IU} / \mathrm{mL}$, while the FT4 was $9.01 \mathrm{pmol} / \mathrm{mL}$ 
(normal range: TSH, 0.5-5.0 $\mu \mathrm{IU} / \mathrm{mL}$; FT4, 8.56$25.6 \mathrm{pmol} / \mathrm{mL}$ ). She had no signs of hypothyroidism, such as low growth rate, abdominal distention, mottled skin, open posterior fontanelle, prolonged jaundice, and lethargy. Thyroid ultrasound was not performed at that time, and the diagnosis of congenital hypothyroidism $(\mathrm{CH})$ was retained. Levothyroxine (L-T4) replacement was given according to the misdiagnosis. However, the treatment of L-T4 had no effect on TSH levels, and FT4 were always elevated (Figure 1).
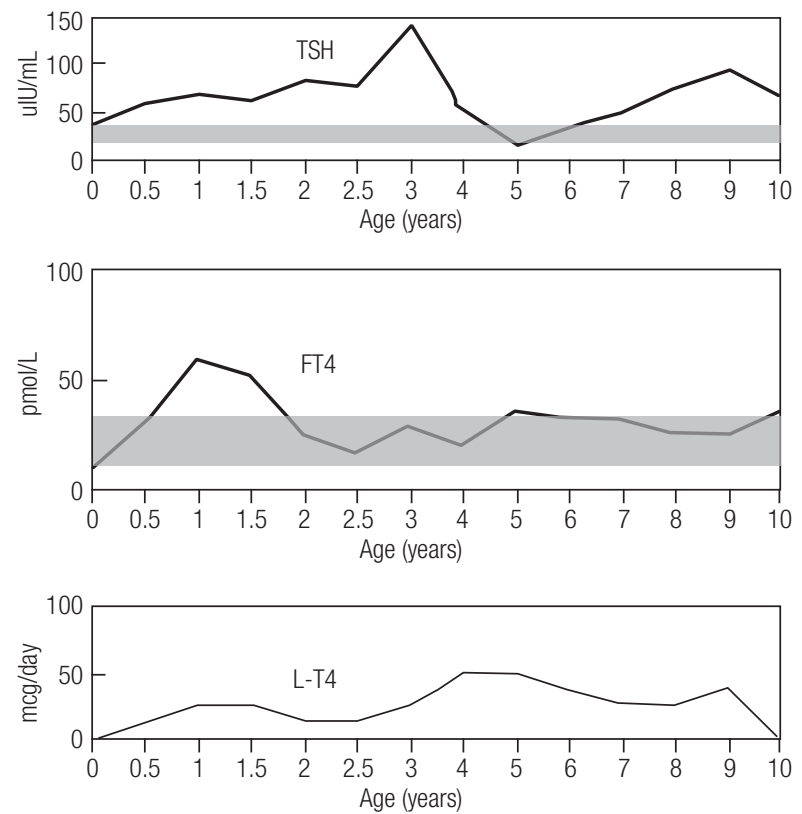

Figure 1. Clinical course of the levels of TSH and FT4 and doses of L-T4 during the 10 year follow-up.

In August 2014, the patient was referred to our endocrine center due to abnormal thyroid function for 10 years. Physical examination showed that the patient had no symptoms of hypothyroidism or hyperthyroidism. Her weight was $25 \mathrm{~kg}$, height was $132 \mathrm{~cm}$, and heart rate was 81 beats/minute (Figure 2). She was slightly thin, but did not exhibit muscle wasting or tremor. We stopped the administration of L-T4 for 2 months and then confirmed the thyroid function of the patient and her family members (Table 1). The patient still showed elevated TSH levels despite high levels of FT3 and FT4, which suggests RTH. Ultrasonography did not find the thyroid gland in the normal place, while the thyroid scan found the enlarged lingual thyroid (Figure 3). Pituitary magnetic resonance imaging (MRI) showed no pituitary tumor in the sella turcica. Her bone age was normal and IQ was 90. Her parents' thyroid function was normal without goiter. The octreotide inhibition test was negative, a decrease of up to $41.98 \%$ in TSH level was observed (Table 2). Interestingly, the level of platelet was $318-448 \times 10^{9} / \mathrm{L}$ (normal range: $100-300$ $\times 10^{9} / \mathrm{L}$ ) during the 10 year follow-up.

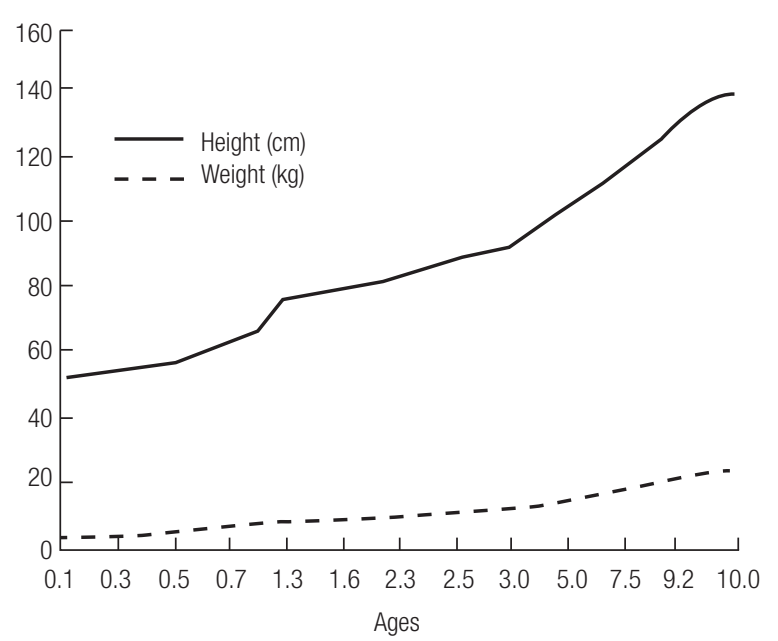

Figure 2. The growth rate (height and weight) of the patient during tenyear follow-up.

Table 1. Detection of thyroid function of family members

\begin{tabular}{lcccc}
\hline Variables & Normal range & Daughter & Mother & Father \\
\hline Age (years) & $/$ & 10 & 39 & 43 \\
TSH ( $\mu$ lU/mL) & $0.34-5.44$ & 67.23 & 2.88 & 4.86 \\
FT4 (pmol/L) & $7.91-20.59$ & 35.42 & 13.08 & 13.42 \\
FT3 (pmol/L) & $2.92-5.93$ & 14.05 & 4.15 & 3.57 \\
TT3 (nmol/mL) & $1.30-3.10$ & 5.89 & 1.89 & 1.52 \\
T44 (nmol/mL) & $66.00-181.00$ & 257.10 & 124.56 & 78.64 \\
Tg (ng/ml) & $1.15-130.77$ & 329.60 & 66.74 & 37.87 \\
TGAb (IU/mL) & $0-34.00$ & $<10.00$ & - & - \\
TPOAb (IU/mL) & $0-12.00$ & 5.96 & - & - \\
Thyroid volume & $/$ & Enlarged & Normal & Normal \\
\hline
\end{tabular}

Figure $3{ }^{99 m T c-p e r t e c h n e t a t e ~ t h y r o i d ~ s c a n ~ s h o w i n g ~ a ~ s i n g l e ~ e n l a r g e d ~}$ lobe with intense uptake in the neck. 
Table 2. Sandostatin inhibition test in the patient

\begin{tabular}{|c|c|c|c|c|c|c|}
\hline Time & $\begin{array}{c}\text { TSH } \\
(\mu \mathrm{lU} / \mathrm{ml})\end{array}$ & $\begin{array}{c}\mathrm{TT3} \\
\text { (nmol/l) }\end{array}$ & $\begin{array}{c}\mathrm{TT4} \\
\text { (nmol/l) }\end{array}$ & $\begin{array}{c}\text { FT3 } \\
\text { (pmol/l) }\end{array}$ & $\begin{array}{c}\text { FT4 } \\
(\mathrm{pmol} / \mathrm{l})\end{array}$ & $\begin{array}{c}\text { TSH/ } \\
\text { basic } \\
\text { value } \\
(\%)\end{array}$ \\
\hline $0 \mathrm{~h}$ & 59.050 & & & 12.22 & 34.14 & 100.00 \\
\hline $2 \mathrm{~h}$ & 46.330 & 3.26 & 188.90 & 10.86 & 30.47 & 78.46 \\
\hline $4 \mathrm{~h}$ & 45.130 & 3.30 & 186.20 & 11.11 & 31.87 & 76.42 \\
\hline $6 \mathrm{~h}$ & 28.320 & 3.29 & 190.00 & 12.46 & 33.00 & 47.96 \\
\hline $8 \mathrm{~h}$ & 27.700 & 3.12 & 180.81 & 11.73 & 32.35 & 46.91 \\
\hline $24 \mathrm{~h}$ & 24.790 & 3.40 & 191.04 & 12.76 & 34.01 & 41.98 \\
\hline
\end{tabular}

Genomic DNA was extracted from peripheral blood leukocytes. Primers were designed to target the flanking intron regions of the exons. All exons of the THR $\beta$ (MIM\# 190160, GenBank NM_001128177.1), THR $\alpha$ (MIM\# 199334.3, GenBank NM_190120), TSHR (MIM\# 603372, GenBank NM_000369.2) and GNAS1 (MIM\# 139320, GenBank NM_080425.3) genes were amplified using PCR. Sequence analysis indicated no mutation in the four genes.

\section{DISCUSSION}

Here we describe a ten-year-old patient with RTH and lingual ectopic thyroid gland. Our patient had no mutation in the THR $\beta, T H R \alpha, T S H R$ and GNASI genes. The patient was misdiagnosed as $\mathrm{CH}$ due to the elevated level of TSH. Ten-year follow-up showed the serum levels of TSH, FT3, and FT4 were always high but without complications.

$\mathrm{RTH}$ is a rare syndrome characterized by decreased tissue responsiveness to thyroid hormone. RTH is mostly caused by mutations in the THR $\beta$ gene, which encode for the thyroid hormone receptor beta unit (2). However, we did not find any mutations in the THR $\beta, T H R \alpha, T S H R$ and GNASI genes. According to previous reports, nearly $10 \%$ of the patients with $\mathrm{RTH}$ had no mutations in the coding region of THR $\beta$ and $5 \%$ of the patients did not have mutations in both the THR $\beta$ and THR $\alpha$ genes $(3,15)$. There are multiple factors, including cofactors, transporters, deiodinases, and binding proteins, that may affect the actions of thyroid hormone (16). It is likely that defects in the factors that may affect the actions of thyroid hormone account for this patient's phenotype.

The different degree of hypothyroidism can be observed in some patients with ectopic thyroid. The patient had the evaluated TSH but normal FT4 at birth. In our opinion, normal FT4 at birth could be related to ectopic thyroid. A similar situation can be observed in the previous literature (14).

Thyrotropin releasing hormone (TRH) stimulating and octreotide inhibition tests could be used in the diagnosis of RTH (17). However, TRH is no longer commercially available in China. The TSH value in our patient remained $41.98 \%$ after 24 hours of injection of somatostatin. In general, suppression of serum TSH in patients with TSH-secreting adenomas was significantly higher than patients with RTH. The elevated level of platelet was not reported previously, and the clinical significance needs more research.

LT-4 supplementation was necessary to the RTH patients with hypothyroidism (18-20). While other patients with RTH rarely require treatment, treatment is clearly necessary in the patient due to the high concentrations of TSH, which may cause further expansion of the lingual thyroid tissue (2l). Bromocriptine ( $\mathrm{Brc})$, a dopamine agonist, has also been reported to suppress inappropriate TSH secretion in RTH, and it can be used alone or in combination with 3,5,3'-triiodothyroacetic acid (TRIAC) (22). However, the patient's parents rejected L-T4 treatment for their child.

In conclusion, we describe the patient who met strict clinical and biochemical criteria for RTH but had no mutations in the considered genes. This patient was even more unusual because she had a lingual thyroid without hyperthyroidism or hypothyroidism symptoms.

Funding statement: this work was supported by the Social Development Project of Huai'an City [grant number: HAS2014005], the Maternal and Child Health Research Project of Jiangsu Province [grant number: F201345] and the Science and Technology Research Projects of Guangxi University [grant number: KY2015LX267].

Trial registration: ChiCTR-CCS-14004734.

Disclosure: no potential conflict of interest relevant to this article was reported.

\section{REFERENCES}

1. Han R, Ye L, Jiang X, Zhou X, Billon C, GuanW, et al. Characteristics of patients with late manifestation of resistance thyroid hormone syndrome: a single-center experience. Endocrine. 2015;50(3): 689-97.

2. Dumitrescu AM, Refetoff S. The syndromes of reduced sensitivity to thyroid hormone. Biochim Biophys Acta. 2013;1830(7):39874003.

3. van Mullem AA, Chrysis D, Eythimiadou A, Chroni E, Tsatsoulis $A$, de Rijke YB, et al. Clinical phenotype of a new type of thyroid hormone resistance caused by a mutation of the TR $\alpha 1$ receptor: 
consequences of LT4 treatment. J Clin Endocrinol Metab. 2013;98(7):3029-38.

4. Maciel LM, Magalhaes PK. Thyroid hormone resistance detected by routine neonatal screening. Arq Bras Endocrinol Metabol. 2010;54(8):723-7.

5. Nettore IC, Cacace V, De Fusco C, Colao A, Macchia PE. The molecular causes of thyroid dysgenesis: a systematic review. J Endocrinol Invest. 2013;36(8):654-64.

6. Ibrahim NA, Fadeyibi IO. Ectopic thyroid: etiology, pathology and management. Hormones (Athens). 2011;10(4):261-9.

7. Candrlic B, Pusic M, Kukuljan M, Cvjetkovic N, Matana Z, Miletić D. Patient with lingual thyroid and squamous cell carcinoma of the tongue base--case report. Coll Antropol. 2012;36 Suppl 2:227-9.

8. Jain A, Singh S, Rastogi A. Hyperthyroidism due to hyperfuctioning lingual thyroid presenting for emergency laparotomy. J Anaesthesiol Clin Pharmacol. 2013;29(1):132-4.

9. Abdallah-Matta MP, Dubarry PH, Pessey JJ, Caron P. Lingual thyroid and hyperthyroidism: a new case and review of the literature. J Endocrinol Invest. 2002;25(3):264-7.

10. Jacob MJ, Ravina M. A rare case of lingual thyroid with hyperthyroidism: A case report and review of the literature. Indian J Endocrinol Metab. 2012;16(3):441-3.

11. Beck-Peccoz P, Persani L, Calebiro D, Bonomi M, Mannavola D, Campi I. Syndromes of hormone resistance in the hypothalamicpituitary-thyroid axis. Best Pract Res Clin Endocrinol Metab. 2006;20(4):529-46.

12. Heather N, Hall K, Neas K, Potter H, Wiltshire E. Growth and development in a child with resistance to thyroid hormone and ectopic thyroid gland. Pediatrics. 2012;129(3):e817-20.

13. Nakajima Y, Yamada M, Horiguchi K, Satoh T, Hashimoto K, Tokuhiro $E$, et al. Resistance to thyroid hormone due to a novel thyroid hormone receptor mutant in a patient with hypothyroidism secondary to lingual thyroid and functional characterization of the mutant receptor. Thyroid. 2010;20(8):917-26.
14. Grasberger H, Ringkananont U, Croxson M, Refetoff S. Resistance to thyroid hormone in a patient with thyroid dysgenesis. Thyroid. 2005;15(7):730-3.

15. Reutrakul S, Sadow PM, Pannain S, Pohlenz J, Carvalho GA, Macchia PE, et al. Search for abnormalities of nuclear corepressors, coactivators, and a coregulator in families with resistance to thyroid hormone without mutations in thyroid hormone receptor beta or alpha genes. J Clin Endocrinol Metab. 2000;85(10):3609-17.

16. Sadow PM, Reutrakul S, Weiss RE, Refetoff S. Resistance to thyroid hormone in the absence of mutations in the thyroid hormone receptor genes. Curr Opin Endocrinol Diabetes Obes. 2000;7:253-9.

17. Beck-Peccoz P, Persani L, Mannavola D, Campi I. Pituitary tumours: TSH-secreting adenomas. Best Pract Res Clin Endocrinol Metab. 2009;23:597-606.

18. Grasberger H, Ringkananont U, Croxson M, Refetoff S. Resistance to thyroid hormone in a patient with thyroid dysgenesis. Thyroid. 2005;15(7):730-3.

19. Heather N, Hall K, Neas K, Potter H, Wiltshire E. Growth and development in a child with resistance to thyroid hormone and ectopic thyroid gland. Pediatrics. 2012;129(3):e817-20.

20. Nakajima Y, Yamada M, Horiguchi K, Satoh T, Hashimoto K, Tokuhiro $E$, et al. Resistance to thyroid hormone due to a novel thyroid hormone receptor mutant in a patient with hypothyroidism secondary to lingual thyroid and functional characterization of the mutant receptor. Thyroid. 2010;20(8):917-26.

21. Sigua-Rodriguez EA, Rangel Goulart D, Asprino L, de Moraes Manzano AC. Conservative management for lingual thyroid ectopic. Case Rep Otolaryngol. 2015;2015:265207.

22. Dulgeroff AJ, Geffner ME, Koyal SN, Wong M, Hershman JM. Bromocriptine and Triac therapy for hyperthyroidism due to pituitary resistance to thyroid hormone. J Clin Endocrinol Metab. 1992;75(4):1071-5. 